\title{
EFEKTIFITAS PELATIHAN TENTANG METODE ASUHAN PASCA KEGUGURAN TERHADAP PENGETAHUAN DAN SIKAP KADER POSYANDU UNTUK MENINGKATKAN KUALITAS PEMBINAAN PROGRAM KAMPUNG KELUARGA BERENCANA DI BANDUNG BARAT
}

\author{
${ }^{1)}$ Lina Haryani, ${ }^{2)}$ Ranti Widiyanti ${ }^{3)}$ Mitra Kadarsih \\ Program Studi Kebidanan, Stikes Jend. A. Yani Cimahi \\ Jl. Terusan Jend. Sudirman Cimahi \\ E-mail : ${ }^{1)}$ lina.mids46@gmail.com,,${ }^{2)}$ rantiwidiyanti88@ gmail.com, ${ }^{(3)} \underline{\text { mitrakadarsih@gmail.com }}$
}

\section{Kata Kunci:}

Pelatihan, Asuhan pasca keguguran, Kader, Keluarga Berencana

\section{Keywords:}

Training, Post abortion care, Cadres, Family Planning

\section{Info Artikel}

Tanggal dikirim: 10-12-2020

Tanggal direvisi: 29-3-2021

Tanggal diterima: 22-07-2021

DOI Artikel:

10.36341/jomis.v5i2.1563

Creative Commons Attribution-

NonCommercial-ShareAlike 4.0 International License.

\begin{abstract}
ABSTRAK
Pendahuluan: Angka kematian ibu di Indonesia saat ini yaitu 305 per 100.000 kelahiran hidup pada tahun 2015 dan diketahui bahwa $4 \%$ kasus kematian ibu terjadi pada kehamilan kurang dari 20 minggu yang disebabkan oleh abortus/keguguran. Oleh karena itu, penting bagi setiap tenaga kesehatan (khususnya dokter dan bidan untuk memahami dan mampu memberikan Asuhan Pasca Keguguran sesuai standar, berdasarkan kompetensi dan kewenangannya. Peran kader posyandu dalam promosi program keluarga berencana dan kontrasepsi pada wanita masih terbatas khususnya pada wanita yang mengalami pasca keguguran. Peran kader dalam asuhan pasca keguguran komprehensif salah satunya dengan memberikan informasi mengenai penggunaan kontrasepsi bagi wanita pasca keguguran sebagai upaya dalam mendukung program keluarga berencana dan meningkatkan kualitas pembinaan kampung KB.
\end{abstract}

Tujuan: penelitian untuk mengetahui efektifitas pelatihan asuhan pasca keguguran dalam meningkatkan pengetahuan dan sikap kader posyandu untuk meningkatkan kualitas pembinaan dan program kampung keluarga berencana di Bandung Barat.

Metode: penelitian menggunakan quasi eksperiment non equivalent control group design dengan sampel 30 kader yang mendapat pelatihan asuhan pasca keguguran komprehensif diambil secara acak. Pengumpulan data penelitian menggunakan kuesioner.

Hasil: penelitian menunjukan bahwa pelatihan asuhan pasca keguguran pada kader posyandu terbukti efektif hal tersebut dapat terlihat dari peningkatan pengetahuan dan sikap kader posyandu sebelum dan setelah diberikan perlakuan.

Rekomendasi: penelitian lebih lanjut dengan menghubungkan variabel pengetahuan dan sikap dengan karakteristik responden yang memengaruhi pelatihan.

\begin{abstract}
Background: The current maternal mortality rate in Indonesia is 305 per 100,000 live births in 2015 and it is known that 4\% of maternal deaths occur in pregnancies of less than 20 weeks caused by abortion/miscarriage. Therefore, it is important for every health worker (especially doctors and midwives to understand and be able to provide post-miscarriage care according to standards, based on their competence and authority). The role of posyandu cadres in the promotion of family planning and contraceptive program for women is still limited, especially for women who experience post abortion. The role of cadres in comprehensive post abortion care is by providing information about the use of contraception for women post abortion as an effort to support family planning programs and improve the quality of village family planning guidance.
\end{abstract}

The purpose: of this research is to determine the effectiveness of post-abortion care training in increasing the knowledge and attitudes of posyandu cadres to improve the quality of family planning village development and programs in West Bandung.

Methods: The study used a quasi-experimental non-equivalent control group design with a random sampling of 30 cadres who received training in comprehensive post- 
abortion. Collecting research data using a questionnaire

Result: showed that post abortion care training for posyandu cadres was proven effective. This could be seen from the increase in knowledge and attitudes of posyandu cadres before and after training.

Recommendations: for further research by linking knowledge and attitudes to characteristics of respondents that influence training.

\section{PENDAHULUAN}

Angka fertilitas total (TFR) di Indonesia pada tahun 2017 mengalami penurunan dibandingkan dengan tahun 2012 yaitu dari angka 2,6 (SDKI 2012) menurun menjadi 2,4 anak per wanita (SDKI 2017). Penurunan TFR tersebut diikuti dengan kenaikan angka prevalensi kontrasepsi (CPR) dari 61,9 persen pada tahun 2012 menjadi 63,6 persen pada tahun 2017.[1] Saat ini Indonesia masih dihadapkan pada permasalahan kesehatan reproduksi, dari hasil analisis determinan kematian ibu yang dilakukan pada tahun 2012 oleh Badan Penelitian dan Pengembangan Kesehatan Kementerian Kesehatan diketahui $4 \%$ kasus kematian ibu terjadi pada kehamilan kurang dari 20 minggu yang disebabkan oleh abortus/ keguguran.[2]

Undang-undang nomor 52 tahun 2009 tentang Perkembangan Kependudukan dan Pembangunan Keluarga, menerangkan bahwa Badan Kependudukan dan Keluarga Berencana Nasional (BKKBN) sebagai suatu badan yang berperan di bidang pengendalian penduduk dan penyelenggaraan keluarga berencana diharapkan mampu menyusun suatu program atau kegiatan yang mendukung dan memperkuat upaya pemenuhan suatu target atau sasaran yang bermanfaat bagi masyarakat secara langsung. Program secara langsung di masyarakat tersebut dapat dilakukan melalui wadah kampung KB sehingga pelaksanaan program-program Kependudukan Keluarga Berencana dan Pembangunan Keluarga (KKBPK) serta program pembangunan lainnya dapat berjalan secara sinergis dan terpadu.[3]

Keluarga Berencana Pasca Keguguran (KBPK) adalah suatu upaya dalam mencegah terjadinya kehamilan dengan penggunaan alat dan obat kontrasepsi setelah mengalami keguguran sampai dengan kurun waktu 14 hari. Keguguran sebagai masalah kesehatan reproduksi pada perempuan usia subur seringkali luput dari perhatian masyarakat, meskipun sesungguhnya sangat banyak terjadi dan memiliki potensi menimbulkan dampak fisik dan psikologis yang serius. Keguguran juga merupakan salah satu penyebab kematian ibu yang utama di trimester pertama kehamilan, sehingga asuhan pasca keguguran yang komprehensif, meliputi konseling, tatalaksana medis, layanan Keluarga Berencana (KB)/ kontrasepsi, rujukan ke layanan lain, serta kemitraan dengan masyarakat perlu dilakukan. Mendukung upaya diatas dibutuhkan peranan berbagai lintas sektor, dalam hal ini BKKBN juga terus berupaya melalui sosialisasi promosi dan konseling KBPK di masyarakat untuk mengurangi angka mortalitas pada ibu dan bayi,.

Hasil data Pencatatan dan Pelaporan Pelayanan Kontrasepsi (Pelkon) pada tahun 2015, jumlah pencapaian KB Pasca Persalinan (PP) dan Pasca Keguguran (PK) meningkat $0,3 \%$ yakni sebesar $52,2 \%(2.610 .922)$ dari perkiraan 5 juta persalinan. Berdasarkan data di atas, maka dapat dijadikan bahan pertimbangan bahwa dibutuhkan dukungan di tingkat Provinsi dan Kabupaten atau Kota dalam upaya pelaksanaan promosi dan konseling KBPK bagi pasangan usia subur melalui berbagai layanan utama dalam pelayanan KB dan kesehatan reproduksi.

Kendala yang dihadapi saat ini di Indonesia adalah belum tersedianya layanan asuhan pasca keguguran, karena setelah mengalami keguguran, ibu hanya mendapatkan layanan medis tanpa ada konseling psikososial, sehingga terjadi perbedaan persepsi di masyarakat mengenai 
makna keguguran dan aborsi. Sehingga, perlu adanya kemitraan dengan masyarakat mengenai asuhan pasca keguguran dalam hal ini bisa disampaikan oleh kader sebagai orang yang dekat dengan masyarakat dan paham mengenai permasalahan kesehatan di masyarakat. Untuk itu, perlu adanya pelatihan untuk peningkatan pengetahuan dan sikap kader terhadap asuhan pasca keguguran.

\section{TINJAUAN PUSTAKA}

Upaya dalam meningkatan kepedulian peran serta masyarakat melalui konseling pendewasaan usia perkawinan (PUP), pengaturan jarak kelahiran, pembinaan dalam ketahanan keluarga, peningkatan kesejahteraan keluarga kecil, bahagia dan sejahtera merupakan definisi Keluarga Berencana menurut UU No. 10 Tahun 1992. KBPK atau keluarga berencana pasca keguguran adalah diberikannya pelayanan KB kepada wanita setelah penanganan keguguran saat berada di fasilitas kesehatan atau 14 (empat belas) hari pasca keguguran.[3] KIE atau Komunikasi Informasi Edukasi adalah suatu proses dalam menyampaikan dan penerimaan pesan-pesan dengan tujuan terjadinya peningkatan dalam pengetahuan, sikap dan perilaku seseorang. KIE KB PP dan PK bertujuan untuk meningkatkan pengetahuan, sikap dan prilaku kepada ibu hamil/ibu pasca persalinan/ibu menyusui ataupun ibu pasca keguguran dan keluarga/pasangannya melalui proses penyampaian dan penerimaan pesan-pesan yang telah dilakukan. Keluarga yang mempunyai anak lebih dari dua merupakan sasaran utama untuk pemberian KIE KB PP dan PK dan untuk meningkatkan kesadaran penggunaan KB PP dan PK pada semua tingkatan usia ibu.[4]

Asuhan pasca keguguran adalah serangkaian intervensi yang dirancang untuk menangani seorang perempuan setelah mengalami keguguran, baik spontan maupun diinduksi.[5]

Tenaga kesehatan/ PLKB/PKB dan kader $\mathrm{KB}$ merupakan petugas yang memberikan KIE mengenai KB PP dan PK secara langsung/ tidak langsung kepada masyarakat dalam penggunaan kontrasepsi melalui saluran komunikasi kepada penerima pesan. Penyampaian informasi dapat disampaikan melalui kegiatan yang berbasis masyarakat seperti posyandu, kelas ibu menyusui dan kelompok kegiatan Bina Keluarga Balita, Bina Keluarga Remaja dan Bina Keluarga Lansia, melalui kegiatan tersebut program KIE KB PK dapat dilakukan secara terintegrasi. Tenaga kesehatan/ PLKB/ PKB dan kader KB yang melakukan KIE KB PK pada masyarakat dapat menciptakan asuhan pasca keguguran yang berkualitas, aman dan menurunkan angka komplikasi pada ibu.(WHO, 2019)[6]

Kampung KB merupakan suatu wahana pemberdayaan masyarakat melalui sebuah desa yang terintegrasi dengan program pembangunan kependudukan, $\mathrm{KB}$ dan pembangunan keluarga serta sektor terkait yang dilaksanakan secara terencana dan terstruktur. Kampung KB bertujuan untuk merubah sikap, perilaku dan cara berfikir masyarakat ke arah yang lebih baik melalui berbagai program sehingga terjadi peningkatan kualitas hidup masyarakat, selain itu untuk meningkatkan peran serta pemerintah, lembaga non pemerintah dan swasta dalam memfasilitasi, mendampingi dan membina masyarakat dalam pelaksanaan program KKBPK dan pembangunan sektor terkait. Dari penjelasan tersebut, dapat disimpulkan bahwa kampung KB yaitu satuan wilayah setingkat RW, dusun, atau yang setara serta memiliki kriteria tertentu dengan sasaran kegiatan selain keluarga yaitu PUS, lansia, dan remaja selain itu keluarga yang memiliki balita, keluarga yang memiliki remaja dan keluarga yang memiliki lansia.[7]

\section{METODE}

Metode penelitian ini menggunakan quasi eksperiment non equivalent control group design dengan sampel diambil secara acak sebanyak 30 kader yang mendapat pelatihan asuhan pasca keguguran komprehensif. Dalam desain ini, sampel pada penelitian di beri pre test terlebih dahulu sebelum diberi perlakuan, kemudian setelah diberi perlakuan sampel 
tersebut di beri post test kembali, dengan demikian hasil perlakuan akan dapat diketahui dengan akurat, karena dapat membandingkan antara sebelum dan sesudah diberikan perlakuan. Penelitian dilakukan pada bulan Juni - Agustus 2020 di Kelurahan Padalarang Kabupaten Bandung Barat.

\section{HASIL DAN PEMBAHASAN}

Karakteristik responden yang terdiri dari umur, pendidikan, lama bekerja dan sumber informasi. Deskripsi dan kesetaraan karakteristik responden tersebut disajikan dalam tabel di bawah ini.

\section{Tabel 1.1 Karakteristik Responden}

\begin{tabular}{ccc}
\hline Variabel & $\begin{array}{c}\text { Frekuensi } \\
(\mathrm{n}=30)\end{array}$ & $\begin{array}{c}\text { Persentase } \\
(\%)\end{array}$ \\
\hline Umur & & \\
$<35$ tahun & 6 & 20.0 \\
$\geq 35$ tahun & 24 & 80.0 \\
Total & 30 & 100.0
\end{tabular}

Pendidikan

$\begin{array}{lcc}\text { SD } & 3 & 10.0 \\ \text { SMP } & 6 & 20.0 \\ \text { SMA } & 19 & 63.3 \\ \text { Perguruan } & 2 & 6.7 \\ \text { Tinggi } & & \\ \text { Total } & 30 & 100.0\end{array}$

Lama Bekerja

$\begin{array}{lcc}\leq 2 \text { tahun } & 4 & 13.3 \\ 2-5 \text { tahun } & 15 & 50.0 \\ \geq 5 \text { tahun } & 11 & 36.7 \\ \text { Total } & 30 & 100.0\end{array}$

Pernah mendapat Informasi Asuhan Pasca Keguguran?

$\begin{array}{lcc}\text { Tidak Pernah } & 17 & 56.7 \\ \text { Ya } & 13 & 43.3 \\ \text { Total } & 30 & 100.0\end{array}$

Sumber Informasi yang didapat mengenai Asuhan Pasca Keguguran?

$\begin{array}{lcc}\text { Tidak Pernah } & 17 & 56.7 \\ \text { mendapatkan } & & \\ \text { informasi } & & \\ \text { Bidan } & 8 & 26.7 \\ \text { Internet } & 1 & 3.3 \\ \text { Televisi } & 2 & 6.7 \\ \text { Lain-lain } & 2 & 6.7 \\ \text { Total } & 30 & 100.0\end{array}$

Karakteristik kader posyandu di Bandung Barat sebagian besar berumur lebih dari 35 tahun sebanyak 24 orang (80\%). Tingkat pendidikan kader sebagian besar SMA sejumlah 19 orang $(63,3 \%)$ dan paling sedikit perguruan tinggi yaitu 2 orang $(6,7 \%)$. dan lama bekerja menjadi kader sebagian besar 2-5 tahun yaitu 15 orang (50\%), sebagian responden belum pernah mendapatkan informasi mengenai asuhan Keluarga Berencana pasca keguguran yaitu sebanyak 17 responden $(56,7 \%)$ dan bagi responden yang pernah mendapatkan informasi mengenai asuhan pasca keguguran sebagian besar bersumber dari bidan yaitu sebanyak 8 kader $(26,7 \%)$

Tabel 1.2 Perbedaan Pengetahuan dan Sikap Kader Posyandu Sebelum dan Setelah Perlakuan

\begin{tabular}{lccl}
\hline Variabel & $\begin{array}{c}\text { Pre } \\
\text { Test }\end{array}$ & $\begin{array}{c}\text { Post } \\
\text { Test }\end{array}$ & P \\
& & & 0,000 \\
\hline Pengetahuan $^{(1)}$ & & & \\
Mean & 77.11 & 94.22 & \\
Median & 73.33 & 93.33 & \\
SD & 7.362 & 4.543 &
\end{tabular}

$\begin{array}{lll}\text { Sikap }^{(2)} & & \\ \text { Mean } & 38.59 & 42.77 \\ \text { Median } & 38.40 & 42.46 \\ \text { SD } & 5.393 & 4.867\end{array}$

0,000

Keterangan: ${ }^{(1)}$ Variabel dianalisis dengan uji

Wilcoxon; ${ }^{(2)}$ Variabel diuji dengan uji - T,

Mean $=$ Rerata $;$ SD $=$ Standar Deviasi 
Hasil Tabel 1.2 diperoleh perbedaan rerata pengetahuan dan sikap sebelum dan setelah dilakukan pelatihan tentang asuhan pasca keguguran menggunakan uji Wilcoxon. Nilai skor tingkat pengetahuan sebelum dan sesudah dilakukan pelatihan,terjadi peningkatan rerata sebanyak 77,11 dengan rerata skor, yaitu 94,22, nilai $\mathrm{p}=0,000$. Artinya pelatihan yang dilakukan kepada kader posyandu berhasil karena efektif dalam meningkatkan pengetahuan kader tentang asuhan pasca keguguran.

Pada variabel sikap terdapat peningkatan sebelum dan sesudah dilakukan pelatihan dengan nilai rerata sebanyak 38,59 dengan rerata skor yaitu 42,77, nilai $\mathrm{p}=0,000$. Hal ini menunjukkan bahwa setelah dilakukan pelatihan pada kader efektif meningkatkan sikap kader terhadap asuhan pasca keguguran

Analisis menunjukkan bahwa terdapat perbedaan bermakna pengetahuan kader sebelum dan sesudah pelatihan asuhan komprehensif pasca keguguran dengan nilai $\mathrm{p}=0,000$. Perbedaannya ditunjukkan dengan meningkatnya nilai median pengetahuan sebelum dan sesudah pelatihan yaitu dari nilai median 73,33 meningkat menjadi 93,33. Pada variabel Sikap terjadi peningkatan setelah diberikan pelatihan yaitu dari 38,59 menjadi 42,77 dan nilai $\mathrm{p}=0,000(\mathrm{P}>0,05)$.

Pelatihan merupakan proses sistematis untuk mengubah perilaku, pengetahuan, dan motivasi seseorang. Pelatihan diyakini sebagai alat yang efektif untuk meningkatkan kualitas dan kapasitas sumber daya manusia untuk lebih produktif.[9]

Penelitian quasi experiment pre post design yang dilakukan oleh Jumiyati et al., 2014 [10] pada kader menunjukkan terjadinya skor peningkatan pengetahuan dan sikap pada kader setelah diberi perlakuan dibandingkan dengan kelompok kontrol dengan hasil $p<0,05$. Hasil penelitian ini sejalan dengan penelitian yang dilakukan oleh Wahyuni et al., 2019 yang menunjukkan adanya pengaruh pelatihan kader posyandu dengan modul terintegrasi terhadap peningkatan pengetahuan dan sikap kader dengan hasil $p<0,05$.[11]

Pelatihan mengacu pada kesempatan belajar terstruktur yang bertujuan untuk membantu peserta pelatihan memperoleh informasi atau keterampilan baru yang akan segera mereka terapkan di tempat kerja dan komunitas peserta pelatihan. Pelatihan dapat meningkatkan pengetahuan peserta tentang informasi tertentu atau memberi kesempatan untuk merefleksikan dan mengubah sikap peserta. Seringkali, pelatihan memungkinkan peserta untuk memperkuat keterampilan yang dibutuhkan untuk melaksanakan prosedur atau aktivitas tertentu, seperti konseling, perubahan kebijakan, melakukan prosedur tindakan atau memasarkan suatu produk. Pelatihan yang efektif memungkinkan peserta untuk belajar dan berlatih menerapkan sikap, pengetahuan dan keterampilan baru dalam lingkungan yang mendukung dan dalam konteks yang relevan dengan pengalaman hidup peserta.[9][12]

Pelatihan yang diberikan pada kader berupa modul yang berisi pengetahuan mengenai asuhan pasca keguguran komprehensif yang merupakan hal baru bagi kader dan hasil dari pelatihan tersebut bisa membuka wawasan dan sikap kader terhadap asuhan pasca keguguran, sehingga kader bisa menerapkan pada masyarakat mengenai asuhan pasca keguguran komprehensif. Peran kader terhadap asuhan pasca keguguran sangat penting di masyarakat salah satu peran kader dalam memberikan asuhan pasca keguguran komprehensif, yaitu memberikan informasi perihal tanda dan gejala keguguran, pendampingan dan membantu rujukan pada wanita yang mengalami keguguran serta penggunaan kontrasepsi pasca keguguran serta untuk menghindari terjadinya kehamilan yang tidak diinginkan di masyarakat.[13][14][15] dan dari hasil penelitian menunjukkan bahwa metode pelatihan asuhan pasca keguguran yang diberikan pada kader terbukti efektif meningkatkan pengetahuan dan sikap kader posyandu di Desa Padalarang Kecamatan Padalarang Kabupaten Bandung Barat.

Peran kader di masyarakat salah satunya adalah mensukseskan program $\mathrm{KB}$ yang merupakan program penting yang dicanangkan pemerintah. Oleh sebab itu, peran kader dalam program KB sangat dibutuhkan khususnya dalam membina program kampung KB di wilayahnya. Dengan meningkatnya 
pengetahuan dan sikap kader terhadap asuhan pasca keguguran komprehensif diharapkan akan meningkatkan kualitas dalam membina kampung KB sebagai program dari BKKBN.

\section{KESIMPULAN}

Hasil penelitian menunjukan terjadi peningkatan skor pengetahuan dan sikap kader setelah diberikan perlakuan dan pelatihan asuhan pasca keguguran pada kader posyandu terbukti efektif, hal tersebut dapat terlihat dari peningkatan pengetahuan dan sikap kader posyandu sebelum dan setelah diberikan perlakuan.

\section{DAFTAR PUSTAKA}

[1] "Riset Nasional Badan Litbangkes | Badan Penelitian dan Pengembangan Kesehatan." https://www.litbang.kemkes.go.id/risetnasional-badan-litbangkes/ (accessed Jul. 21, 2021).

[2] BKKBN, BPS, Survey Demografi Kesehatan Indonesia (SDKI). Jakarta, 2017.

[3] BKKBN. "PERATURAN KEPALA BADAN KEPENDUDUKAN DAN KELUARGA BERENCANA NASIONAL NOMOR 24 TAHUN 2017 TENTANG PELAYANAN KELUARGA BERENCANA PASCA PERSALINAN DAN PASCA KEGUGURAN," 2017.

[4] F. Juliaan and M. Anggraeni, "PENGGUNAAN KONTRASEPSI PADA WANITA PASCA MELAHIRKAN DAN PASCA KEGUGURAN, SDKI 2012," $J$.

Kesehat. Reproduksi, vol. 6, no. 2, pp. 108-116, Mar. 2016, doi: 10.22435/kespro.v6i2.4751.108-116.

[5] Kementerian Kesehatan RI, Pedoman nasional asuhan pasca keguguran yang komprehensif. 2020.

[6] "WHO | Health worker roles in providing safe abortion care and post- abortion contraception," WHO, 2019, Accessed: Dec. 09, 2020. [Online]. Available:

http://www.who.int/reproductivehealth/ publications/unsafe_abortion/abortiontask-shifting/en/.

[7] A. M. Sorhaindo and J. L. Morris, "SERAH: Supporting Expanded Roles for safe Abortion care by Health workers - A working group to enable the implementation of the WHO guidelines for expanded roles of health workers in safe abortion and postabortion care," Int. J. Gynecol. Obstet., vol. 134, no. 1, pp. 1-2, Jul. 2016, doi: 10.1016/j.ijgo.2016.04.003.

[8] "Kampung KB | Tentang Program." https://kampungkb.bkkbn.go.id/about (accessed Dec. 09, 2020).

[9] A. Suhepi and T. Y. R. Syah, "the Influence of Training Design, Individual Characteristics, and Work Environment on Training Transfer and Its Impact on Employee'S Performance," Int. J. Econ. Commer. Manag. United Kingdom, vol. VI, no. 3, pp. 103-123, 2018, [Online]. Available: http://ijecm.co.uk/.

[10] N. Jumiyati, N. S. A, and A. Margawati, "Pengaruh Modul Terhadap

Peningkatan Pengetahuan, Sikap Dan Praktek Kader Dalam Upaya Pemberian Asi Eksklusif," Gizi Indones., vol. 37, no. 1, p. 19, 2014, doi: 10.36457/gizindo.v37i1.147.

[11] S. Wahyuni, J. C. Mose, and U. Sabarudin, "Pengaruh pelatihan kader posyandu dengan modul terintegrasi terhadap peningkatan pengetahuan, sikap dan keikutsertaan kader posyandu," J. Ris. Kebidanan Indones., vol. 3, no. 2, pp. 95-101, 2019, doi: 10.32536/jrki.v3i2.60.

[12] K. Turner, C. Wegs, and B. RandallDavid, Effective training in reproductive health: Course design and 
delivery: Trainer's manual. 2011.

[13] B. Ganatra, "Health worker roles in safe abortion care and post-abortion contraception," Lancet Glob. Heal., vol. 3, no. 9, pp. e512-e513, 2015, doi: 10.1016/S2214-109X(15)00145-X.

[14] C. Glenton, A. M. Sorhaindo, B. Ganatra, and S. Lewin, "Implementation considerations when expanding health worker roles to include safe abortion care: A fivecountry case study synthesis," $B M C$ Public Health, vol. 17, no. 1, pp. 1-13, 2017, doi: 10.1186/s12889-017-4764-z.

[15] World Health Organization, "Safe Abortion Care and Post-Abortion Contraception," p. 81, 2015. 